\title{
Geopolitički zaokret liberalnih slovenskih krugova u Primorskoj pred Prvi svjetski rat
}

\author{
IGOR IVAŠKOVIĆ \\ Univerza v Ljubljani, Ekonomska fakulteta \\ Ljubljana, Slovenija \\ igor.ivaskovic@ef.uni-lj.si
}

\begin{abstract}
Autor analizira pisanje primorskih slovenskih liberalnih novina u vrijeme balkanskih ratova 1912. i 1913., prikazuje geopolitičke stavove toga političkoga kruga te ga smješta u širi kontekst sukoba različitih vizija jugoslavenstva. Specifičan položaj primorskih Slovenaca i geopolitičko značenje Trsta odrazili su se na naklonjenost toga dijela Slovenaca što širemu južnoslavenskom konceptu, koji je trebao biti poluga za slovensku političku emancipaciju. Isprva se taj dio Slovenaca zauzima za ujedinjenje južnoslavenskih naroda unutar Habsburške Monarhije, no analizirano razdoblje donosi preokret koji se očituje u ispuštanju habsburškoga okvira u prvom krugu balkanskih ratova. Drugi je pak krug prouzročio isključivanje Bugarske iz južnoslavenskih koncepata, čime se dio primorskih Slovenaca priklanja užoj viziji južnoslavenske državne ideje sa Srbijom u središnjoj ulozi.
\end{abstract}

Ključne riječi: balkanski ratovi; Primorska; jugoslavenska ideja; Trst; geopolitika

\section{Uvod}

Jugoslavenstvo je opsežan koncept koji prodire u cijeli spektar društvenih područja. Dakako, najčešće uzburkava strasti koncept političkoga jugoslavenstva, pod kojim razumijemo ideju o zasnivanju zajedničke države određenih južnoslavenskih naroda ili pak strateško političko partnerstvo odnosno konfederalne veze više država u okviru južnoslavenskoga savezništva. Istina je da je ta problematika bila predmetom proučavanja brojnih istraživanja, no često 
su na rub znanstvenoga interesa gurnute južnoslavenske alternative koje nikad nisu zaživjele, a u određenim su povijesnim razdobljima igrale važnu ulogu na društveno-političkim pozornicama. Jedno od takvih pitanja je i izostanak najvećega južnoslavenskog naroda, Bugara, iz obiju realiziranih varijanti jugoslavenske države u XX. stoljeću. Ovaj rad ima ambiciju istražiti upravo proces oblikovanja južnoslavenskoga političkoga koncepta kod liberalnoga dijela primorskih Slovenaca, što je sudbonosno utjecalo na status Bugara u slovenskim očima, a posljedično ostavilo i bitan trag na povijest Hrvata i ostalih južnoslavenskih naroda.

Predmet proučavanja su primorski Slovenci, točnije izdanja njihovih političkih glasila iz Trsta i u određenoj mjeri iz Gorice, koja su upravo krajem XIX. i početkom XX. stoljeća doživljavala svojevrsni vrhunac političke utjecajnosti. Potonje se temeljilo na činjenici da je u Trstu tada živjelo brojnije slovensko pučanstvo nego primjerice u Ljubljani, a ta se slovenska zajednica u političkom smislu vrlo dinamično oblikovala zahvaljujući životu uz talijansku većinu. S geopolitičkoga je stajališta proučavanje slovenskoga odnosa prema jugoslavenskoj ideji utoliko zanimljivije jer je to rubni južnoslavenski narod, koji je svoj odnos prema ideji jugoslavenstva oblikovao u političkom natjecanju s Talijanima i Nijemcima. Upravo zbog prijetnje potencijalne periferizacije Slovenci nikako nisu mogli ostati indiferentni prema fundamentalnim geopolitičkim pitanjima, a to su opseg južnoslavenske državne jedinice, njezino političko središte i njezino međunarodno pozicioniranje. Ovaj rad stoga prikazuje geopolitički obrat politički najaktivnijega i ujedno najisturenijega dijela Slovenaca kroz prizmu slike koju su u svojim izvješćima o balkanskim ratovima 1912. i 1913. donosila glasila slovenskih liberala iz Trsta i Gorice.

\section{Položaj primorskih Slovenaca i značenje Trsta u Habsburškoj Monarhiji}

Slovenski politički koncepti koji su bili smješteni u južnoslavenski okvir, bez obzira na to s kojega su ideološkoga pola dolazili, bili su obilježeni rubnim geografskim položajem Slovenaca u odnosu na druge južnoslavenske narode. U to su se vrijeme Slovenci još uvijek neuspješno pokušavali otresti statusa takozvanoga nepovijesnog naroda, koji u svojoj prošlosti nije uspio stvoriti vlastitu državu, što je dakako uvelike otežavalo slovenska političkoemancipacijska nastojanja u kontekstu Habsburške Monarhije. Priključivanje što širega slovenskoga etničkog područja u južnoslavensku tvorevinu, bilo to unutar ili izvan habsburškoga okvira, bilo je temeljni politički cilj Slovenaca prije Prvoga svjetskog rata. Pritom se možemo složiti s konstatacijom Marka Zajca ${ }^{1}$ da je upravo jugoslavenstvo bilo oblik slovenskoga nacionalizma u habsburško

ZAJC, Slovenci in protislovja, 1. 
doba jer je ta ideja omogućavala ostvarenje tadašnjih slovenskih nacionalnih interesa.

Slovenske su se političke stranke krajem XIX. i početkom XX. stoljeća zbog pomanjkanja statusa „povijesnoga” naroda naslanjale na Hrvate, koji su također mnogo energije ulagali u integraciju svojih područja u Trojednu Kraljevinu. Ipak, između slovenskih liberala (Narodno-napredna stranka) i najjače konzervativne stranke (Slovenska pučka stranka, slov. Slovenska ljudska stranka) postojale su znatne razlike u metodama ostvarenja temeljnih političkih ciljeva. U oblikovanju slovenskoga narodnoga koncepta bitno je dalje dospjela konzervativna struja, što nikako ne implicira pomanjkanje državnih ideja kod liberala. Konkurentska prednost potonjih svakako je bio dominantan položaj liberala u gradovima Ljubljani, Trstu i Gorici, a upravo su oni u tadašnjoj državi bili ulaz u svijet visokoga obrazovanja i državne administracije te posljedično i odskočna daska za učinkovitije djelovanje na državnoj razini. U austrijskom dijelu države građanstvo je i inače bilo liberalnijega svjetonazora, čemu se u drugoj polovini XIX. stoljeća pridružila i izrazita nacionalna komponenta. $^{2}$ To je dinamiziralo politički život u gradovima s mješovitom nacionalnom strukturom, a posebice je bila interesantna situacija u Trstu, gdje su se preklapali u prvom redu talijanski, slovenski i njemački interesi, i događaji u tom gradu često su nagovještavali političke prijelome na državnoj razini. Uključivanje Trsta u austrougarsko carinsko područje 1887., rast luke i njezine veze prema Dalmaciji i Bosni i Hercegovini (BiH) te gradnja željeznice prema Beču utjecali su na iznimnu geopolitičku važnost grada. ${ }^{3}$ To je također utjecalo na bržu industrijalizaciju širega gradskog područja, a demografski je rast bio neizbježna posljedica činjenice da je Trst s bruto dohotkom po stanovniku prestigao čak i Beč. ${ }^{4}$ Doseljavali su se uglavnom Slovenci iz okolnih ruralnih područja, što nije samo stimuliralo njihovu političku aktivnost nego je omogućilo i pojavu novih političkih pokreta, prije svega socijalno-demokratskoga, koji je sve više narušavao konzervativno-liberalni duopol. Najprije su Slovenci dnevno migrirali u grad i elemente gradske kulture prenosili na selo, a potom su se počeli i stalno naseljavati u pojedinim četvrtima, npr. u četvrti Sv. Jakob. ${ }^{5}$ To je uzrokovalo rušenje dotad komplementarnoga odnosa slovenskoga seljaka i talijanskoga građanina. U samom je gradu 1911. živjelo približno 57 000 Slovenaca, što ipak nije bila ni trećina gradskoga stanovništva. Većinu su dakako činili Talijani, a znatne su bile i njemačka te hrvatska uz nešto manju

\footnotetext{
BRUCKMÜLLER, „Nove raziskave zgodovine”.

VERGINELLA, „Prihod vlaka v Trst”.

WINKLER, Wahlrechtsreformen und Wahlen, 51-53.

VERGINELLA, Družina v Dolini pri Trstu, 8.
} 
židovsku, češku i srpsku zajednicu. ${ }^{6}$ Pozitivni demografski trendovi za slovensku zajednicu implicirali su ne samo artikulaciju nacionalnih zahtjeva, ${ }^{7}$ nego su politička glasila sve jasnije izražavala nadu da bi u budućnosti grad mogao dobiti posve slovenski karakter: „Talijani su tu u Trstu, za sada još u većini, stoga su i gospodari u ovoj kući. Kako su se ovdje našli, to ni sami ne znaju. Došli su slučajno iz Italije. Naselili su se na slovenskoj zemlji, i to na onoj točki koja je za Sloveniju najvažnija..."

Dinamika društvenoga i političkoga života u Trstu imala je mnogo šire učinke u Habsburškoj Monarhiji. Upravo su naime Trst, Primorska regija i Istra bili žarište talijanskoga iredentizma, a tamošnji Hrvati i Slovenci vlastima u Beču pokušavali su se prikazati kao zaštitni stup austrijskih interesa na tom dijelu Jadrana te tako pridobiti simpatije za viši stupanj vlastite političke emancipacije. ${ }^{9} \mathrm{U}$ drugoj polovini XIX. stoljeća jačao je i trend povećanja njemačkoga i potom slavenskoga kapitala u osiguravajućim društvima, što je u talijanskoj većini budilo strah od gubitka gospodarske i posljedično političke prevlasti u gradu. Zbog toga su talijanski mediji otvoreno optuživali središnju vlast, koja je, po njihovu mišljenju, bila odgovorna za protutalijanske procese u Trstu. ${ }^{10} \mathrm{U}$ to su se vrijeme primorski Slovenci uglavnom naslanjali na hrvatske političke partnere, a to je savezništvo svoj politički okvir temeljilo na ideji preuređenja Dvojne Monarhije u trodijelnu, što je impliciralo uspostavu treće državne jedinice koja bi bila jednakopravna austrijskom i ugarskom dijelu. I dok su mađarske političke elite toj ideji bile nesklone, u Beču su upravo u takvu razvoju vidjeli mogućnosti za smanjenje ugarske moći. S aspekta liberalnih Slovenaca takve su okolnosti i načelna sklonost centralnih vlasti nudile priliku za ostvarenje slovensko-hrvatskoga entiteta koji bi, prema njima, trebao imati tri središta: Zagreb, Ljubljanu i Trst. ${ }^{11}$ Isprva se činilo da će južnoslavensko pitanje slovenski liberali rješavati s Hrvatima te iskoristiti svoj bolji položaj u gradovima u odnosu na slovenske konzervativce. $U$ tom je procesu naime Ivan Tavčar za kratko vrijeme preuzeo vodeću ulogu povezivanja s hrvatskim

\footnotetext{
6 Prema popisu iz 1910., približno 51,9 \% stanovnika govorilo je talijanski, 24,8 \% slovenski, $5,2 \%$ njemački, $1,1 \%$ „srpskohrvatski”, $0,3 \%$ služilo se nekim drugim jezikom, a bilo je čak 17 \% stranih državljana (Spezialortsrepertorium; LAMPE, Yugoslavia as history, 75; PIRJEVEC, Trst je naš!, 19).

7 GRDINA, Slovenci med tradicijo in perspektivo, 211-216.

$8 \quad$ Italijani so tu $v$ Trstu, in so sedaj še v večini, so torej za enkrat gospodarji v tržaški hiši. Kako so se tu znašli, tega menda še sami ne vedo. Prišli so slučajno iz Italije. Naselili so se na slovenski zemlji, in sicer na oni točki, ki je za Slovenijo najvažnejša... („Naš Trst”, Edinost/Trst/, 17. 8. 1912., 1-2).

$9 \quad$ PIRJEVEC, Trst je naš!, 40-41; RAHTEN, Zavezništva in delitve, 105-149.

10 MILLO, L'élite del potere, 125-126; KACIN-WOHINZ, TROHA, Slovensko-italijanski odnosi, 29.

11 Pirjevec u: PEČENKO, Cesarski Trst in Slovenci.
} 
strankama, ${ }^{12}$ a rješenje za „povijesnost” Nijemaca i Talijana pokušao je naći u povijesnom hrvatskom državnom pravu te pozivanjem na Pragmatičku sankciju Hrvatskoga sabora iz 1712. godine. ${ }^{13}$ Prema njoj, Hrvatska je pristala na vladavinu Habsburgovaca i ako bi ta obitelj ostala bez muških potomaka, no uz uvjet da Monarhija uključuje i pretežno slovenska područja. Unatoč tomu, pri povezivanju s Hrvatima uskoro je slovenske liberale pretekla katolička politička struja, za što velike zasluge idu Antunu Mahniću, koji je svojim djelovanjem na prijelomu stoljeća postavio čvrste temelje slovensko-hrvatskoga savezništva s katoličkim predznakom. To je slovenskim liberalima u Trstu i Gorici donekle ograničilo manevarski prostor, što je djelomično utjecalo na daljnji razvoj njihova političkoga programa.

Proces postupne zamjene ruralnoga urbanom okolinom kod primorskih je Slovenaca potaknuo i prijelaz od konzervativnoga k liberalnom političkom polu. Naime, uz preuzimanje građanskih navika smanjila se važnost religiozne komponente identiteta, a sve važniju ulogu preuzimala je nacionalna dimenzija koja se odražavala u jezičnoj pripadnosti. Na to je utjecao prije svega dodir s talijanskim narodnjačkim skupinama, koje su kulturni i gospodarski prodor Talijana na cijelo područje Jadrana smatrale glavnim elementom svojega poslanstva. ${ }^{14}$ Slovenski je liberalni krug u takvim okolnostima predstavljao antitezu grupama poput one Ruggera Timeusa te je dokazivao da se slovenstvo i slavenstvo mogu također artikulirati u liberalno-građanskoj političkoj opciji. Proces nacionalizacije masa na području Trsta bio je dakle nešto drugačiji od onoga na štajerskim i koruškim područjima, ${ }^{15}$ a poticali su ga i neki događaji na razini države. Primjer toga bila je izborna reforma koja je donijela širenje glasačkoga prava i po kojoj je Trst imao pravo na pet zastupnika u središnjoj skupštini, što je povećalo i opći interes za politiku i konkurenciju između Slovenaca i Talijana. ${ }^{16} \mathrm{U}$ toj su se utakmici Slovenci naslanjali na jugoslavenski koncept, u kojem su tražili politički okvir koji će biti jednako snažan kao što je bio iredentistički program s tezom o kontinuitetu između rimske i talijanske civilizacije kod njihovih političkih suparnika. ${ }^{17}$

U političkom životu primorskih Slovenaca centralno mjesto zauzimalo je udruženje Edinost, osnovano 1874. godine. Temeljni medij svake tadašnje politički angažirane udruge bio je časopis, pa je tako i Edinost 1876. počela izdavati istoimeni list. Upravo je on među 64 slovenska časopisa koji su u Trstu

\footnotetext{
RAHTEN, Zavezništva in delitve, 73-83; MATKOVIĆ, „Ivan Tavčar”, 151-159.

RAHTEN, Zavezništva in delitve, 64.

KACIN-WOHINZ, TROHA, Slovensko-italijanski odnosi, 31-32.

CVIRN, „Med nacionalizmom in nacionalno koeksistenco”.

CVIRN, Razvoj ustavnosti, 151.

VIVANTE, Irredentismo adriatico, 136-138; VERGINELLA, „Zgodovinjenje slovensko-italijanske meje".
} 
izlazili od drugoga dijela XIX. stoljeća do Prvoga svjetskog rata bio najutjecajniji slovenski medij. ${ }^{18}$ Nastupi predstavnika Edinosti, koja je u svojim rukama imala sve bitne niti narodnoga, političkoga, kulturnoga i gospodarskoga života Slovenaca, najrealnije su odražavali ideju slovenskoga narodnjačko-liberalnog pokreta u tom dijelu Primorske. ${ }^{19}$ Značenje časopisa Edinost možemo iščitati i iz zapisa poznatoga hrvatskog pravaša iz Istre Vjekoslava Spinčića kad je pokušao dočarati važnost lista Naša sloga za Hrvate: „Ko hoče, da prouči život našega naroda u Istri od godine 1870 do 1916: njegovo probudjivanje i osvješčivanje, njegov prosvjetni i gospodarski napredak, njegove borbe za škole, za jezik u uredima i javnom životu, njegove izborne borbe u opčinska zastupstva, u pokrajinski sabor i u zastupničku kuću carevinskog vijeća; ko hoće, da sve to prouči, taj valja da prolista 'Našu slogu'. Ona je zrcalo života hrvatskoga naroda Istre [...] Medju Hrvatima Istre vršila je zadaću sličnu onoj, što vrši od godine 1876 'Edinost' medju Slovencima Trsta i Istre, a donekle i Goričke."”o Edinost je uistinu imala središnji položaj među Slovencima, u prvom redu u liberalnim krugovima, a u srži njezina programa bilo je isticanje slovenskoga identiteta. Njezin je utjecaj u obzir uzimala čak i vlast u Beču, koja je upravo na inzistiranje Edinosti odredila ponovni popis stanovništva u Trstu 1911. godine. $^{21}$

\section{Trijalizam}

Prije balkanskih ratova u okviru političkoga diskursa o južnoslavenskom pitanju najčešće se iskazivao koncept treće državne jedinice koja bi trebala nastati pored austrijske i mađarske. Ideja trijalizma zapravo je bila pokušaj austrijskoga manevra kojim bi se otklonile manjkavosti dualizma, a prije svega to je bio plan smanjenja političke snage Ugarske na račun nove južnoslavenske jedinice s Hrvatskom u središtu. Edinost je o tom planu pisala još duboko u XIX. stoljeću, no pritom je sa slovensko-hrvatskoga partnerstva ponekad prelazila na šire povezivanje Slovenaca, Hrvata i Srba: „Mnogi Slovenci još uvijek sanjaju o 'ujedinjenoj Sloveniji'. [...] No slabi rezultati posljednjih godina trebaju nas uvjeriti da smo mi Slovenci sami preslabi da bismo takvo što izvojevali. [...] Najučinkovitija pomoć bit će ako se udružimo s Hrvatima i Bošnjacima. [...] Ako se to učini, onda ni srpska kraljevina nema uvjeta zasebnoga opstanka: nema smisla da polovica Srba bude u kraljevini, a polovica u Austriji. Veća i jača slovensko-hrvatsko-bosanska država prirodnom će silom kraljevinu pri-

\footnotetext{
MARUŠIČ, „Od Maribora do Trsta”.

PAHOR, Slavjanska sloga, 27-28 i 69.

Isto, 26.

Pirjevec u: PEČENKO, Cesarski Trst in Slovenci.
} 
vući k sebi." ${ }^{22}$ Nakon aneksije BiH Edinost je zastupala nacrt koji je predviđao stvaranje Kraljevine Ilirije, koja bi uključivala hrvatska i slovenska područja te netom anektirane teritorije, a Vojvodina bi ostala dijelom Ugarske. Prema tom planu, Slovenija bi unutar Ilirije trebala imati status pokrajine, a sačinjavali bi ju Kranjska, Gorica i Gradiška, Trst sa sjevernom Istrom, Koruška i Štajerska južno od rijeke Drave. Taj je nacrt Edinost prenijela s oduševljenjem: „Mađarskom bi se dijelu pridružila Galicija, Bukovina i poljski dio Šlezije. Njemački bi se dio sastojao od Češke, češkoga dijela Šlezije, Moravske, Gornje i Donje Austrije, Tirola, Salzburga te Koruške i Štajerske sjeverno od Drave. Jugoslavenska bi se država sastojala od Hrvatske, Slavonije, Bosne, Hercegovine, Dalmacije, Istre, Trsta, Gorice, Kranjske, Južne Koruške od Villacha do Donjega Dravograda i Štajerske južno od Drave. Granica bi prolazila od Villacha do Osijeka. Od Osijeka bi dalje do Beograda graničio Dunav."23

Trijalističkome konceptu, razumljivo, nisu bili skloni ni na mađarskoj ni na talijanskoj strani. Edinost je prenosila pisanje mađarskoga časopisa Aj Ujsag da bečki politički krugovi pokušavaju isključiti mađarski utjecaj na Balkanu. ${ }^{24}$ Soča, glasilo slovenskih goričkih liberala, s ironijom je prenosila pisanje mađarskih listova da bi državna samostalnost Južnim Slavenima samo štetila. ${ }^{25}$ Istovremeno su Talijani bili uvjereni da je trijalizam usmjeren upravo protiv njih te da promovira ideju slavenske dominacije u Dalmaciji, Primorju, Istri i Trstu. Soča je prenosila pisanje talijanskoga lista Il Piccolo della Sera: „U tom principu vide Slaveni mogućnost ostvarenja onoga što se u prošlosti činilo samo snom marginalaca: sastavljanje novoga jugoslavenskoga kraljevstva, koje bi pored Kranjske te slovenskoga dijela Štajerske i Koruške opsezalo i cijelo dalmatinsko primorje (i naše Primorje!) i koje bi bilo povezano s Austro-Ugarskom samo u osobi vladara te bi imalo vlastito političko zastupstvo. Slavenski napad na Trst. Ovaj novi imperijalizam stvorio je udruženja za takozvanu obranu granica u Ljubljani te je Slavenima dao sredstva i neočekivanu energiju

\footnotetext{
22 Mnogi Slovenci sanjajo še vedno o „zedinjenej Sloveniji”. ... Pa slabi uspehi zadnjih let nas morajo prepričati, da smo mi Slovenci sami preslabi, da bi kaj tacega izvojevali. /.../ Najtemeljiteja pomoč pa bo, da se politično združimo s Hrvati in Bošnjaki. ... Ako se to izvede, potem pa tudi srbska kraljevina nema pogojev obstanka v sebi: da bi bila polovica Srbov v kraljevini, polovico pa $v$ Avstriji, to nema smisla, večja in močnejša slovensko-hrvatsko-bosanska država tudi z naravno silo srbsko kraljevino k sebi potegne („Ilirija”, Edinost, 17. 8. 1887., 1-2).

23 Madjarskemu delu bi se priklopilo Galicijo, Bukovino in poljski del Šlezije. Nemški del bi sestojal iz Češke, češkega dela Šlezije, Moravske, Gornje in Doljne Avstrije, Tirolske, Solnograške ter Koroške in Štajerske severno od Drave. Jugoslovanska država bi sestajala iz Hrvatske, Slavonije, Bosne, Hercegovine. Dalmacije, Istre, Trsta, Goriške, Kranjske, Južne Koroške od Beljaka do Spodnjega Dravograda in Štajerske južno od Drave. Meja bi bila na severu in izhodu Drava od Beljaka do Osjeka. Od Osjeka dalje do Belgrada bi mejila Donava („Trializem”, Edinost, 24. 6. 1909., 2).

24 „Trializem na vidiku!?”, Edinost, 11. 5. 1909., 1.

25 „Trializem in Madžari”, Soča (Gorica), 20. 7. 1909., 3.
} 
za dobivanje Trsta." ${ }^{26}$ S nastavkom diskursa o preuređenju države postajalo je sve jasnije da će se trijalistički plan vrlo teško ostvariti. Edinost je već 1909. pisala da je to doduše lijepa ideja, koja međutim ovisi o previše drugih čimbenika: „Bečka vlada vrlo vjerojatno na taj program neće pristati prije nego mađarski šovinizam. Ali onda imaju važnu riječ i Česi, jer njihovo državno pravo ima još veću povijesnu utemeljenost nego hrvatsko. Protiv ostvarenja češkoga prava nastupaju pak svi Nijemci i već dva milijuna Nijemaca u Češkoj faktor je s kojim moraju računati svi Slaveni. Nijemci u Češkoj nikad neće dopustiti Česima ostvarenje državnoga prava bez vlastite autonomije." ${ }^{27}$

Uz očekivane poteškoće na razini Habsburške Monarhije Slovenci iz Trsta razmišljali su i o hrvatsko-srpskom sporu o statusu BiH. Hrvati su naime težili pripajanju Trojednoj Kraljevini, a Srbi su bili skloni autonomiji BiH unutar Monarhije. Slovenski su liberali u tom kontekstu pokušali predložiti teritorijalnu podjelu koja bi zadovoljila sve strane. Nacrt Gregora Žerjava polazio je od ideje stvaranja posebnoga entiteta unutar Monarhije koji bi činile tri pokrajine, a svaka bi imala kraljeva namjesnika i pokrajinsku skupštinu. ${ }^{28}$ Žerjavov plan na neki je način bio prijelazna faza od zastupanja povijesnoga državnog prava prema branjenju takozvanoga prirodnog prava. Plan je naime predviđao nužnost srpske jedinice unutar habsburškoga južnoslavenskog entiteta i ona bi, prema tom planu, trebala imati teritorijalni diskontinuitet jer Vojvodina i veći dio BiH, koje je Žerjav pripisivao Srbima, ne bi imale teritorijalni kontakt. Primorski bi se Slovenci vrlo vjerojatno zadovoljili i prijedlogom Henrika Hanaua iz rujna 1909., prema kojem bi posebnu jedinicu, Jugoslaviju, tvorili Hrvatska, Slavonija, BiH, Dalmacija, Istra, Trst, Gorica, Kranjska, Donja Koruška i Donja Štajerska. Mađarsku bi državu na drugoj strani činile Ugarska, Transilvanija, Galicija i Bukovina, a ostale pokrajine pripale bi njemačkom dijelu Monarhije. U Koruškoj i Štajerskoj granica bi bila Drava, a Villach, Kla-

\footnotetext{
$26 V$ tem principu vidijo Slovani možnost uresničiti to, kar se je zdelo v preteklem časa samo sen eksaltirancev: sestava novega jugoslovanskega kraljestva, ki bi obsegalo poleg Kranjske ter slovenskega dela Štajerske in Koroške vse dalmatinsko Primorje (pa naše Primorje tudi!) ter bi bilo $z$ druženo $z$ Avstro-Ogrsko samo v osebi vladarja ter bi imelo svoje lastno zastopstvo. Slovanski naskok na Trst. Ta novi imperializem je ustvaril družbe za takozvano obrambo mej v Ljubljani ter je dal sredstva in nepričakovane energije Slovanom po pridobitvi Trsta („Slovani in Lahi ob Adriji”, Soča, 27. 12. 1910., 1).

27 Dunajska vlada na ta program najbrže ne privoli poprej, nego madjarski šovinizem. Ali potim imajo še Čehi važno besedo, kajti njih državno pravo ima še večjo zgodovinsko zaslombo nego hrvatsko. Proti uveljavljenju češkega prava pa sigurno nastopijo vsi Nemci in že 2 milijona Nemcev na Češkem je faktor, s katerim morajo vsi Slovani računati. Nemci na Češkem ne privole nikdar Čehom državnega prava brez lastne narodne avtonomije („Trializem - češko državno”, Edinost, 23. 1. 1909., 2).

28 PLETERSKI, „Trializem pri Slovencih”, 169-184.
} 
genfurt i Maribor ne bi bili dio Jugoslavije. Na zapadu bi granica išla između Tarvisija i Spodnjega Loga, s tim da bi prvi bio u njemačkom dijelu. ${ }^{29}$

Trijalizam po želji slovenskih liberala nije mogao proći na široj političkoj pozornici. Sve se češće naime počelo spominjati rješenje koje bi omogućilo nastanak južnoslavenske državne jedinice, zadovoljilo austrijske ambicije za pristup Trstu te talijanske želje da ni Istra ni Primorska regija ne pripadnu Iliriji. Općenito su se treće jedinice najviše pribojavali Česi, koji su smatrali da bi u tom slučaju ostali sami u njemačkom dijelu Monarhije. ${ }^{30}$ Spekuliranje s idejom užega trijalizma, bez Slovenaca, odnosno samo s jednim njihovim dijelom, najteže su, razumljivo, prihvaćali upravo primorski Slovenci. U slovenskim časopisima u Trstu i Gorici sve su se češće pojavljivali članci koji su kritizirali takvu ideju. U toj se kampanji na udaru našlo i povijesno hrvatsko državno pravo: „Ne na prašnjavim pergamentima, nego na životu, ne na povijesnom, nego na narodnom pravu moramo temeljiti naše zahtjeve."31 Ta je kritika bila posljedica činjenice da je Pragmatička sankcija iz 1712. od područja na kojima je živjelo i slovensko stanovništvo spominjala samo Štajersku, Korušku i Kranjsku, ali nijednom riječju Goricu, Trst i Istru. Posljedično su slovenski liberali smatrali da bi ih naslanjanje na hrvatsko državno pravo ostavilo izvan hrvatske, odnosno ilirske državne jedinice: „Kako će biti na jugu ako se ostvari hrvatsko državno pravo? Od slovenskih će pokrajina samo Kranjska s granicom u Julijskim Alpama i Karavankama pripasti novoj jedinici; sve će ostale pokrajine biti izgubljene za nas jer će ih prisvojiti Talijani i Nijemci. Zato i ima za nas Slovence 'narodna autonomija' veću važnost nego hrvatsko državno pravo." 32 Nesklonost prema institutu hrvatskoga povijesnoga državnog prava slovenski su liberali pokazali i kada je 1911. u Zagrebu izašla brošura Put do trializma, u kojoj je bio nacrt nove jedinice samo s hrvatskim područjima: „Nama se čini da je to pitanje bačeno među Jugoslavene kao kost koju bismo mi trebali glodati, a drugi bi pojeli cijelo pečenje. [...] Čak i ako bi se sve jugoslavenske zemlje Monarhije udružile u jednu upravnu cjelinu, one bi ipak bile premalene da bi mogle predstavljati treći jednakopravni čimbenik u Monarhiji. [...] A kako tek Hrvati to misle sami postići?!"33 Slovenci iz Trsta

\footnotetext{
29 „Trialističen zemljevid habsburške monarhije”, Edinost, 9. 9. 1909., 2; KOCUTAR, „Habsburška monarhija”, 11-35.

30 KLABJAN, Češkoslovaška na Jadranu, 68.

31 Ne na zaprašene pergamente, ampak na življenje, ne na historiška, ampak na narodna prava moramo opirati svoje zahteve („Avstrijski problem II”, Edinost, 27. 12. 1908., 1-2).

32 Kako pa na jugu, ako se vresniči hrvatsko državno pravo? Od slovenskih dežel pripadala bo $k$ večemu Kranjska $z$ mejo Julskih planin in Karavank; vse druge pokrajine bi pa bile za nas izgubljene, ker bi si jih prisvojili Lahi in Nemci. Zato pa ima tudi za nas Slovence „narodna avtonomija” več veljave nego hrvatsko državno pravo („Trializem - češko državno”, Edinost, 23. 1. 1909., 2).

33 Nam se zdi, da je to vprašanje vrženo med Jugoslovane kakor kost, na kateri naj bi glodali, da bi med tem pojedli drugi pečenko. ... Tudi, ko bi združili vse jugoslovanske dežele monarhije v eno
} 
prosvjedovali su i prilikom objave članka u tršćanskom hrvatskom časopisu Trializam, koji je u srpnju 1912. trećoj jedinici priključio i Goricu i Rijeku, no istovremeno ispustio Trst: „Tako dakle! Rijeka da, a Trst ne! Normalno, jer je Rijeka hrvatski grad pa se ne smije izgubiti! A Trst [...] može vrag odnijeti! [...] Prste dalje, gospodo oko 'Trializma', od našega narodnog vlasništva, od našega tršćanskog teritorija!" 34

U takvu se ozračju sve više slovenskih liberala počelo okretati alternativama, u prvom redu prema srpskoj viziji jugoslavenstva. U okviru toga na udaru se našao i katolički karakter trijalističke ideje: „Klerikalci sanjaju o velikoj jugoslavenskoj klerikalno uređenoj državi, zato toliko govore o skupini jugoslavenskih katolika i pritom pokazuju pesnice pravoslavnim Srbima. Klerikalci su krivi što Srbi nisu zagrijani za ponuđenu koncentraciju, oni ih sami guraju u san o 'Velikoj Srbiji s Petrom Karađorđevićem na čelu'. Ne možemo se onda nimalo čuditi Srbima ako izjavljuju da žele autonomiju Bosne te se izmiču koncentraciji katolika, jer znaju da bi time stavili svoje glave pod sjekire katoličkih dželata." ${ }^{35}$ Slične su se kritike redale sve do balkanskih ratova: „Klerikalci već dulje vole govoriti o južnoslavenskoj državi u okviru naše Monarhije. [...] Ta država ima biti posve katolička, zato i ne govore ništa o Srbima. Srbi su pravoslavci; dakle, ne pašu u katoličku jugoslavensku državu." ${ }^{36}$ Za slovenske je konzervativce u ono vrijeme ključ južnoslavenske zajednice uistinu bilo slovensko-hrvatsko jedinstvo, koje se temeljilo na pripadnosti zapadnoj kulturi, rimokatoličkoj vjeroispovijesti i habsburškom državnom okviru, a liberali su na prvo mjesto stavljali slavenstvo. To je impliciralo središnji položaj Srbije, čime su liberali prkosili i Beču: „Ili će Jugoslaveni izvan Monarhije k nama ili mi k njima! Onaj dio koji će imati veću snagu privlačnosti, taj će privući k sebi ostale. Zagreb ili Beograd? S Monarhijom ili bez nje?"37

upravno celoto, bi bile te dežele vendarle premajhne, da bi mogle veljati kakor tretji enakopravni faktor v monarhji. ... A kako naj bi Hrvatje sami dosegli to?! („Varanje s trializmom”, Edinost, 3. 9. 1911., 1).

34 Tako torej! Reka da, Trst pa ne! Seveda, ker je Reka hrvatsko mesto, se ne sme izgubiti! Trst pa (...) lahko vzame vrag! ... Le prste proč gospoda okolo „Trializma” od naše narodne lasti, od našega tržaškega ozemlja! („Trializem”, Edinost, 25. 7. 1912., 1).

35 Klerikalci sanjajo o veliki jugoslovanski državi prav po klerikalno urejeni, zato govorijo toliko o skupini jugoslovanskih katolikov, pri čemur kažejo pesti pravoslavnim Srbom. Tako zakrivljajo Klerikalci, da se Srbi ne morejo čisio nič ogrevati za ponujano koncentracijo, tako jih oni sami pehajo v sanje o „Veliki Srbiji s Petrom Karagjorgjevičem na čelu”. Nič se ni čuditi potemtakem Srbom, če izjavljajo, da hočejo avtonomijo Bosne in se odtegujejo nastavljeni koncentraciji katolikov, ker vedo, da bi s tem postavili svoje glave pod sekire rabljev s katoliško firmo („O trializmu”, Soča, 9. 3. 1911., 1).

36 Klerikalci že precej časa radi govorijo o jugoslovanski državi v okvirju naše monarhije. ... Ker ima biti ta država hudo katoliška, zato ne govorijo čisto nič o Srbih. Srbi so pravoslavni; torej ne tičejo v katoliško jugoslovansko državo („Trialistične šalobarde”, Soča, 16. 4. 1912., 1-2).

37 Ali pridejo Jugoslovani izven monarhije $k$ nam ali mi $k$ njim! Oni del, ki bo imel večjo atrakcijsko silo, oni bo tudi privlačeval na sebe ostali del. Zagreb ali Beograd? Z monarhijo ali proti njej? 
Može se sažeti da su liberalni Slovenci od gubitka vodeće uloge u povezivanju s Hrvatima počeli gledati prema Srbiji, koja je i u pisanjima Edinosti dobivala ulogu vodeće sile u južnoslavenskim državnim planovima, u koje je tada bila uključena i Bugarska, što će čak i u vrijeme Kraljevine Jugoslavije 30 -ih godina XX. stoljeća potvrditi jedan od važnijih predstavnika slovenskih liberala Andrej Gabršček: „Pa nismo nimalo prikrivali da želimo ujedinjenje svih Slovenaca, Hrvata i Srba, možda i Bugara, u jednu veliku Jugoslaviju." 38

\section{Geopolitička situacija na Balkanu}

Nakon povratka dinastije Karađorđević na prijestolje Kraljevina Srbija našla se u nepovoljnoj situaciji. Aneksija BiH pomaknula je cijelu jugoistočnu granicu Austro-Ugarske prema Srbiji. Pored nesklone politike Beča, ni odnosi s Bugarskom nisu bili stabilni još od rata 1885. godine. Sporna su bila makedonska područja, koja su obje strane smatrale svojima. Bugarska je pak bila u dobrim odnosima s Rusijom i sve je više pokazivala ambiciju postati vođa Balkanskoga poluotoka. Njezina je diplomacija pozdravila i aneksiju $\mathrm{BiH}$ jer je to značilo prvi odmak od odredbi Berlinskoga kongresa, što je probudilo bugarsku želju za ponovnim dobivanjem južnih i zapadnih teritorija koje je Bugarska samo nakratko bila dobila Sanstefanskim sporazumom. Aneksija je pak sa srpskoga stajališta samo potvrdila da se veliki njemački Drang neće zaustavljati sve dok potpuno ne podredi područja Balkana. Pretežni dio javnosti čak je zahtijevao novi srpski ustanak. Časopis Slovenski jug 27. rujna 1908. piše: „Rat Austriji, što prije rat Austriji, za svaku cijenu rat protiv Austrije! Naša jugoslavenska propaganda je danas uistinu revolucionarna. Nisu više potrebne riječi, nego hrabrost i krv, puno hrabrosti i puno krvi za jedno veliko povijesno djelo južnih Slavena. Udružite se južni Slaveni u ratu protiv Austrije." ${ }^{39}$ Ipak, u ono vrijeme predstavnici Kraljevine Srbije čuvali su se radikalnih istupa. ${ }^{40} \mathrm{Na}$ srpskom su dvoru naime shvaćali da je Austro-Ugarska sposobna brzo poraziti Srbiju, koju tada još nisu bili spremni poduprijeti ni zapadni saveznici ni Rusija. Za srpskoga kralja nije dakle bilo oportuno slijediti želje dijela naroda o takozvanom oslobođenju $\mathrm{BiH}$, nego se ograničio na intenzivno diplomatsko djelovanje. Regent Aleksandar upravo je u to vrijeme boravio u Sankt Peterburgu i ruskome caru predstavljao ideju šire Jugoslavije

(„Jugoslavija in habsburška monarhija”, Edinost, 28. 4. 1912., 1).

38 Saj nismo kar nič prikrivali, da hočemo zedinjenje vseh Slovencev, Hrvatov, Srbov, morda tudi Bolgarov v eno samo veliko Jugoslavijo (GABRŠČEK, Goriški Slovenci, 145).

39 BAKIĆ, Ideologije jugoslovenstva, 118.

40 STANKOVIĆ, Nikola Pašić, 20. 
koja bi uključivala Srbiju, BiH, Crnu Goru, Vojvodinu, Kosovo te hrvatska i makedonska područja. ${ }^{41}$

Politička djelatnost intenzivirala se i u samoj $\mathrm{BiH}$, gdje su brojne srpske udruge zahtijevale pripojenje toga područja Srbiji. Aneksija je ubrzala homogenizaciju srpskih južnoslavenskih koncepata, a istovremeno su sve trijalističke ideje u srpskim glasilima označavane kao protusrpske. Habsburški su Srbi pri suprotstavljanju trijalizmu u načelu pristajali na svaki oblik dualizma, ali uz uvjet da se BiH ne pripoji Ugarskoj. Edinost je popratila ta događanja sljedećim riječima: „[...] nemoguća je Velika Hrvatska uslijed hrvatsko-srpskoga antagonizma. Iz toga izvire i protivljenje bosanskih Srba trijalizmu jer za sebe traže nacionalnu autonomiju u okviru zajedničke Monarhije. S dualizmom se bosanski Srbi slažu sve dok za njih nema opasnosti pripojenja Ugarskoj. Protiv takva pripajanja Srbi bi se postavili solidarno s Hrvatima i ostalim cislajtanskim narodima, a pri pokušaju pripojenja ovom dijelu Monarhije napravili bi zajedničku frontu s Mađarima." ${ }^{2}$ Srbi su dakle pokušali sačuvati status quo te na taj način postići neku vrstu autonomije unutar Habsburške Monarhije.

Na drugoj je strani Kraljevina Srbija tražila način za svoj prodor na jugoistok. Osmansko Carstvo, oslabljeno Mladoturskom revolucijom, bilo je idealan suparnik. Srpska je diplomacija brzo uspjela sklopiti savez is Bugarskom i s Grčkom te Crnom Gorom. Upravo je srpsko-bugarsko savezništvo imalo bitne geopolitičke implikacije za habsburške Južne Slavene, što se može iščitati iz izjave srpskoga ministra vanjskih poslova Milana Milovanovića bugarskome kolegi Stefanu Paprikovu: „Za nas je u svemu tome još jedan važan aspekt koji nas potiče na sporazum s Bugarskom. Sve dok mi nismo povezani s vama, naš će utjecaj na Hrvate i Slovence biti beznačajan. Unatoč različitoj vjeri, ti ljudi u velikoj mjeri imaju sličnu kulturu kao mi. No, oni ne vide Srbiju kao centar koji bi ih mogao privući. Posve će drugačije biti ako mi ostvarimo snažan blok. Onda će svi pravoslavni i katolički Srbi, Hrvati i Slovenci u susjednoj Monarhiji početi neizbježno gravitirati k nama." ${ }^{33} \mathrm{Na}$ sličan je način srpski

\footnotetext{
41 SAJOVIC, Od male Srbije, 20-23.

42. ... nemožna (je) Velika Hrvatska vsled hrvatsko-srbskega antagonizma. Od todi tudi opozicija bosanskih Srbov proti trializmu, ker zahtevajo zase marveč nacijonalno avtonomijo v okvirju skupne monarhije. $Z$ duvalizmom se sprijaznujejo bosanski Srbi le tako dolgo, dokler ni za njih nevarnosti združenja z Ogrsko. Proti priklopljenju z Ogrsko bi se Srbi postavili solidarno s Hrvati in cislajtanskimi narodi, proti inkorporaciji v tostransko državno polovico pa bi napravili fronto skupno z Madjari („Narodna avtonomija”, Edinost, 12. 4. 1911., 1-2).

43 For us there is another important consideration which speaks for the advantage of an agreement with Bulgaria. As long as we are not allied with you, our influence over the Croats and Slovenes will be insignificant. Outside of our differences of faith, these people have to a great degree the same culture we have. They do not see Serbia as a center, however, able to attract them. It will be something else all together, when you and we form a powerful bloc. Then all Orthodox and Catholic Serbs, Croats and Slovenes in the neighboring Monarchy will begin inevitably to gravitate toward us (HALL, The Balkan Wars, 10).
} 
veleposlanik u Bugarskoj Miroslav Spalajković francuskome veleposlaniku izrazio bojazan da će Franjo Ferdinand preuzimanjem habsburškoga prijestolja stvoriti treću državu u Monarhiji, koja bi mogla privući i Srbiju i Crnu Goru. ${ }^{44}$ Motive za Prvi balkanski rat ne treba dakle tražiti samo u borbi protiv Osmanskoga Carstva, nego je to s geopolitičkoga stajališta bio bitan korak u borbi protiv austrijskih ambicija na Balkanu. I dok su Crnogorci tražili način kako osvojiti Sandžak, Skadar, Kosovo i Metohiju, Grci su bili zainteresirani za osvajanje Soluna te otoka u Egejskom moru, u prvom redu Krete. Ni područja naseljena Albancima nisu bila posve sklona Turcima. I tu je naime već 1910., kao i kod bosanskohercegovačkih muslimana u XIX. stoljeću, došlo do buna protiv centralizacije. ${ }^{45}$ To je ujedno bila i manifestacija želje za povezivanjem pretežno albanskih provincija u autonomnu Albaniju u okviru Osmanskoga Carstva.

S aspekta šire međunarodne zajednice, stvaranje saveza između Bugarske i Srbije odgovaralo je Rusiji, koja se nakon poraza u ratu s Japanom 1905. i diplomatskoga povlačenja pri aneksiji $\mathrm{BiH}$ željela ponovo angažirati na Balkanu. Pod ruskim su mentorstvom bila bar privremeno potisnuta nesuglasja glede Makedonije, a pregovori koji su trajali od jeseni 1911. rezultirali su dogovorom u ožujku 1912. godine. Sporazum je uključivao stavku o minimalnom broju vojnika, to jest 200000 bugarskih i bar 150000 srpskih. ${ }^{46}$ Određena su i područja djelovanja pojedinih trupa. Srpska je vojska trebala djelovati na vardarskom bojištu, a u slučaju uključenja Rumunjske na strani Osmanskoga Carstva trebala je poslati pomoć Bugarskoj. I Bugarska je obećala intervenirati ako bi sa zapada nasrnula austrougarska vojska. Što se makedonskoga teritorija tiče, područje istočno od Rodopa i rijeke Strume trebalo je pripasti Bugarskoj, sjeverno i zapadno od Šar-planine prisvojila bi Srbija, a ostalo bi privremeno dobilo autonoman status te bi bilo predmetom podjele nakon rata uz arbitriranje ruskoga cara. Ubrzo su i ostali članovi balkanske koalicije sklopili međusobne dogovore, nakon čega je u listopadu počelo objavljivanje rata. Bilo je očito da se Osmansko Carstvo neće moći obraniti, no ipak je sukob nosio i mnogo upitnika. Nije naime bilo jasno koliko će rat trajati, koliko će žrtava biti i kako će se pojedine velike sile postaviti prema novoj situaciji.

Odjeci balkanskih sukoba među slovenskim liberalima

Balkanske sukobe Slovenci nisu shvaćali jednoznačno. Liberalni krug političara u prvom je redu bio zadovoljan time što su događanja na Balkanu uni-

\footnotetext{
RAHTEN, Slovenska ljudska stranka, 126-128.

BESHIRI, „Neovisnost Albanije 1912.”

HALL, The Balkan Wars, 12.
} 
jela iskru spora u najjaču slovensku političku opciju. Naime, glasilo Slovenske pučke stranke Slovenec, pod utjecajem Janeza Evangelista Kreka, izražavalo je simpatije za „bratske" Srbe i Crnogorce ${ }^{47}$ a drugačije mišljenje imao je Ivan Šusteršič, dugogodišnji parlamentarni vođa i Habsburškoj Monarhiji najlojalniji pripadnik slovenske konzervativne struje. Edinost je na drugoj strani već sam početak ratnih zbivanja dočekala na strani protuturske koalicije, pa je primjerice s oduševljenjem prenosila govore crnogorskoga kralja i pozivala na mobilizaciju i ostale Slavene. ${ }^{48}$ Časopis je opisivao rat kao sukob malih protiv velikoga, čak i kao boj križa protiv polumjeseca. O svakoj se pobjedi crnogorskih, srpskih ili bugarskih jedinica pisalo sa zanosom: „[...] svi austrijski Jugoslaveni šaljemo im u ovom trenutku izraze svojih bratskih simpatija želeći njihovu oružju blagoslov s nebesa!"49 Uredništvo Edinosti pritom je polagalo velike nade u bratimljenje Srba i Bugara, što je trebalo biti jamcem povijesnoga uspjeha svih ,Jugoslavena”. ${ }^{50}$ Udruga je u to vrijeme po uzoru na događanja u Dalmaciji ${ }^{11}$ skupljala novčanu pomoć za „braću na Balkanu”. ${ }^{52}$

Članovi protuturske koalicije za to su vrijeme napredovali različitim brzinama. U Traciji je bugarska vojska bilježila zapanjujuće uspjehe te se nakon serije pobjeda našla pred vratima Istanbula. Turci su u tom trenutku bili spremni na sklapanje primirja i zamrzavanje postojećega stanja, no bugarske su ambicije porasle te su tražili potpuni poraz suparnika i osvajanje glavnoga grada. To precjenjivanje vlastite snage, uz slabosti u logističkom sistemu te koleru, Bugare je ipak stajalo realizacije planova. Indikativno je da im u tom trenutku nijedna velika sila nije ponudila pomoć koja bi kao posljedicu imala potpunu promjenu stanja ne samo na području zahvaćenom ratom nego i šire na europskom kontinentu. Bugarska je tim uspjehom mogla postati novi centar moći u (južno)slavenskom svijetu, čime ne bi samo ugrozila srpske ambicije nego se to moglo odraziti i na položaj Rusije kod ostalih slavenskih naroda. Srpska je vojska istovremeno naišla na relativno snažan otpor Turaka kod Kumanova, ali je nakon te pobjede također napredovala mnogo brže od očekivanja te je zauzela sjevernu i centralnu Makedoniju. Još je važnije bilo zauzimanje sjeverne Albanije, čime je srpska vojska prodrla do Jadrana i prouzročila nezadovoljstvo Beča, koji je u tome vidio ugrozu za vlastiti pristup Crnom moru. Bilo je jasno da će austrijska diplomacija intervenirati u sukobu radi sprječavanja nekontroliranih promjena u njezinu susjedstvu. Za razliku od Bugara i Srba, Crnogorci

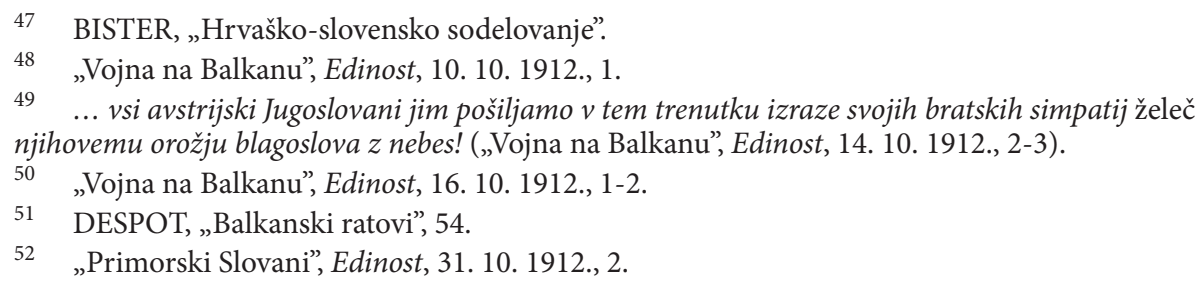


su se suočili s mnogo većim problemima. Osvojili su doduše dobar dio Sandžaka, ali zbog loše organizacije nisu postigli cilj osvajanja Prizrena. ${ }^{53}$ Grčka je također osvojila nešto manji teritorij, ali je imala ključnu ulogu u sprječavanju dostave turske pomoći iz Azije. Budući da su Grci u to vrijeme imali spremniju mornaricu, Turci su tražili pomoć od Velike Britanije, no London se na to oglušio. Grčka je ipak imala drugi problem, a to je bilo loše dogovoreno razgraničenje s Bugarskom, što je već u prvom krugu balkanskih sukoba stvaralo napetosti između saveznika. ${ }^{54}$ Grčkoj nije bila sklona ni njemačka politika, što je Edinost protumačila kao strah pred emancipacijom svih južnoslavenskih naroda: „[...] poraze turske vojske Nijemci osjećaju nekako kao svoje poraze. [...] Nakon pobjedonosnoga obračuna balkanskih Jugoslavena s Turskom i položaj austrijskih Slavena i Jugoslavena posebno postao bi potpuno drukčiji [...] na balkanskoj se pozornici sada odigrava pretposljednji čin jugoslavenske drame. Posljednji će se čin odigrati drugdje. Tada ni izvanbalkanski Slaveni neće više biti samo gledatelji koji plješću nego će i sami djelovati na pozornici." ${ }^{55}$ Čini se da je nova realnost na Balkanu uzrokovala dodatni rast samopouzdanja kod slovenskih liberala iz Trsta. To se uz uspjehe protuturske koalicije temeljilo i na uvjerenju da Trst ima takvu geopolitičku težinu da ostale velesile nikada Austriji ne bi dopustile da sama upravlja tim gradom: „Najpametnije što može naša (austrijska) diplomacija napraviti jest da prihvati nove činjenice. Na lijep način još može nešto učiniti, a prijetnjama neće postići ništa. Ako će dakle postavljati nekakve svoje zahtjeve, njih će moći realizirati samo ratom. No to neće biti rat Austrije protiv Srbije, nego europski rat." ${ }^{56}$

Usprkos početnim porazima Turska je uspjela obraniti Istanbul, pobijediti kod Čataldže i sačuvati tri strateške utvrde (Drinopolje, Skadar i Janjina) te posljedično nadzor nad važnim trgovačkim koridorima. U tom su se trenutku u sukob na diplomatskom polju uključile i velesile. ${ }^{57}$ Najprije je Habsburška Monarhija posredovala kod bugarskoga predsjednika Ivana Evstratieva Gešova, no ubrzo su inicijativu preuzeli Britanci, koji su pregovore uspjeli dovesti u London. Počelo se 25. studenog 1912. s bugarsko-turskim sporom, koji je

53 DESPOT, The Balkan Wars, 81-82.

54 HALL, The Balkan Wars, 67.

55 ... občutijo Nemci poraze turške armade nekako kakor svoje poraze. ... Po zmagonosnem obračunu balkanskih Jugoslovanov s Turčijo bi tudi položaj avstrijskih Slovanov in Jugoslovanov še posebej postal vse drugačen, negoli je bil doslej. ... na Balkanskem pozorišču se odigrava sedaj predzadnje dejanje Jugoslovanske drame. Zadnje dejanje se bo igralo kje drugje. Takrat tudi izvenbalkanski Slovani ne bodo le gledalci, ki aplavdirajo, temveč posežejo tudi sami v razvoj dejanja na odru („Balkanska epopeja”, Edinost, 27. 10. 1912., 1).

56 Najpametneje, kar more naša (avstrijska) diplomacija storiti, je, da se sprijazni z dogodki. Zlepa utegne kaj doseči, z grožnjami pa prav ničesar. Ako bo torej stavila kake zahteve, jih bo mogla uveljaviti le $z$ vojno, to pa ne $z$ vojno Avstrije proti Srbiji, temveč z evropsko vojno („Nesposobna avstrijska diplomacija", Edinost, 10. 11. 1912., 1).

57 DESPOT, The Balkan Wars, 113-120. 
riješen relativno brzo, već 3. prosinca. Bugarska je dobila pravo prometovanja pored Drinopolja, a Turci su smjeli zadržati utvrdu. Grad je doduše ostao neriješeno pitanje, ali nijedna strana tada više nije bila zainteresirana za nastavak rata. Drukčiji je slučaj bio s Grčkom, koja je inzistirala na Janjini, što je mirovni proces odvelo u drugi krug. ${ }^{58}$

Dana 13. prosinca počeo je drugi krug pregovora, koji je trebao redefinirati geopolitičke odnose na Balkanu. Austrougarska diplomacija ulagala je napore u sprječavanje srpskoga pristupa moru i teritorijalno razdvajanje Srbije i Crne Gore. Prvi je cilj postignut priznanjem neovisnosti Albanije, što je poduprla Italija. Geostrateški važan grad Drač postao je prijestolnicom, a novoj je državi dodijeljen i Skadar, koji su tada još opkoljavale crnogorske trupe. Srbija je uz rusku pomoć dobila „samo” Đakovicu, što su s ogorčenjem prihvatili slovenski liberali u Edinosti: „Za čije se interese dakle spustila naša [austrijska] diplomacija u tu albansku vatru?! Odgovara nam sama diplomacija opravdavajući ulogu zaštitnika Albanaca tvrdnjom da je životni interes Monarhije samostalna albanska državna tvorba kao protuteža slavenskim balkanskim državama, u prvom redu Srbiji! Isti državni interes Monarhije nalaže onemogućavanje Srbiji da dobije svoju luku na Jadranskom moru. Ako austrijska diplomacija uistinu vjeruje u ovakav interes, onda za tu sudbonosnu pogrešku imamo samo jedno objašnjenje: ta diplomacija nema ni najprimitivnijega razumijevanja istinskih interesa naše države u balkanskom pitanju!" ${ }^{99} \mathrm{Na}$ sličan je način i jedan od utjecajnijih članova slovenske zajednice u Trstu, odvjetnik, poduzetnik i tršćanski gradski vijećnik Otokar Rybář, tumačio da albanska nacija uopće ne postoji te da Austrija „želi stvoriti albansku državu i podupirati ju vojno i financijski samo zato da zabije klin u jugoslavensko meso [...] i da nama Jugoslavenima pokvari veselje zbog jugoslavenskih pobjeda" ${ }^{60}$ Izvještaji o ratnim događanjima na Balkanu nisu dakle skrivali ideološko usmjerenje časopisa. Pritom su idealizirali Južne Slavene upletene u sukob, a svi njihovi suparnici bili su stavljeni u negativan kontekst.

HALL, The Balkan Wars, 69-72.

Za čegave interese se je torej spustila naša diplomacija $v$ ta albanski ogenj?! Odgovor nam daje ta diplomacija sama s tem, da svojo protektovsko vlogo nad Albanci opravičuje s trditvijo, da je življenski interes monarhije, da samostojna albanska državna tvorba tvori protitežje proti slovanskimi balkanskim državam, v prvi vrsti pa proti - Srbiji! Isti državni interes monarhije da zabranjuje, da bi Srbija dobila svoje pristanišče ob Jadranskem morju. Če avstrijska diplomacija res veruje $v$ ta interes, potem imamo za to usodno zmoto le eno pojasnilo, ki je: da ta diplomacija nima niti najprimitivnejega razumevanja resničnih interesov naše države pri balkanskem vprašanju! („V službi Italije”, Edinost, 15. 2. 1913., 1-2).

60 hoče ustvariti albansko držav in jo hoče podpirati militarično in financijelno le v ta namen, da zabije zagvozdo v jugoslovansko meso ... ter da nam Jugoslovanom pokvari veselje, ki smo je imeli na jugoslovanskih zmagah („Dogodki na Balkanu”, Edinost, 7. 6. 1913., 1). 


\section{Poraz ideje balkanskoga saveza}

U vrijeme prvoga kruga balkanskih sukoba liberalna zajednica Slovenaca iz Trsta snažno je propagirala ideju neovisnoga balkanskog saveza, odnosno neke vrste unije pod vodstvom Južnih Slavena. ${ }^{61}$ Prema tom mišljenju, i Albanija bi se morala podrediti toj novoj državnoj tvorbi. ${ }^{62}$ Štoviše, u krugu Edinosti bili su uvjereni da je to samo uvod u sveslavensko udruživanje na jugoistoku Europe: „Borba kršćanskih naroda na Balkanu u posljednjoj je fazi [...] I budući da su svi ti narodi tako usko povezani vjerski, kulturno i nacionalno, sada krvare i bore se na Balkanu i za svoju nacionalnu ideju. I budući da su ti narodi članovi naše velike slavenske obitelji, spojeni sa svima nama kojima je Božja providnost poklonila slavensko rođenje i dala nam slavensku dušu, $s$ najnježnijom $i$ istovremeno najčvršćom vezom narodnoga i krvnoga srodstva, ovo je gigantska borba naroda na Balkanu - slavenska epopeja." ${ }^{63}$ Ratni uspjesi Bugara, Crnogoraca i Srba za Edinost su, slično kao i za brojne hrvatske političke krugove, ${ }^{64}$ bili jamac preuređenja Habsburške Monarhije: „Ne staroj Austriji! Nju definitivno treba likvidirati. Neka nastupi nova Austrija, u kojoj neće biti povlaštenih vladajućih naroda, Austrija koja će biti pravedna prema Slavenima." ${ }^{\prime 65}$ U pozadini rasprava o balkanskom savezu uvijek se pojavljivala i misao o zajedničkoj državi svih Južnih Slavena: „Ideja udruživanja svih Jugoslavena od Drave do Drine, od Jadrana do Egeja i Crnoga mora u jednu državu dobiva sve više pristaša. [...] Tako je u Trstu i Primorskoj. Kamo god pogledamo, vidimo na svim poljima javnoga života da se naše ljude, naš element, naš narod proganja i ugnjetava - da je cijeli državni sistem uređen tako da favorizira Nijemce i Talijane, a zapostavlja Slovence! [...] Upravo zato moramo gospodi u Beču reći jasno i bez okolišanja da danas doduše još nema govora o jugoslavenskom iredentizmu, no da ne bi bilo čudno ako se pojavi. [...] U Srbiji vlada potpuna građanska jednakost, tamo je demokratična uprava i potpuna politička sloboda. ${ }^{36}$ Primjetno je da se u člancima nastupalo ne

\footnotetext{
61 „O balkanski zvezi”, Edinost, 5. 3. 1913., 2.

62 „Balkanska zveza”, Edinost, 25. 2. 1913., 1.

63 Borba krščanskih narodov na Balkanu je na zadnji etapi ... In ker so v teh narodih tako ozko spojeni verski, kulturni in nacijonalni moment, krvavi sedaj in se bore na Balkanu tudi za svojo nacijonalno idejo. In ker so ti narodi člani velike slovanske družine, spojeni z nami vsemi, ki nam je božja previdnost poklonila slovansko rojstvo in nam dala slovansko dušo, po najnežnejih, a ob najtrdnejih vezeh narodnega in krvnega sorodstva, je ta gigantska borba narodov na Balkanu slovanska epopeja („Dozoreva dan”, Edinost, 23. 3. 1913., 1).

64 MATKOVIĆ, „Political Narratives”.

65 Ne Alt-Oesterreich! Ta (se) mora definitivno likvidirati. Na plan naj stopi nova Avstrija, $v$ kateri ne bo privilegiranih gospodujočih narodov, Avstrija, ki jo bo pravičnost tudi do Slovanov („Alt-Oesterreich - heraus!”, Edinost, 17. 11. 1912., 1).

66 Ideja, da bi se združili vsi Jugoslovani, od Drave do Drine, od Adrije do Egeja in Črnega morja $v$ eno državo, pridobiva vedno več tal, vedno več pristašev. ... Tako je v Trstu in na Primorskem.
} 
samo protiv talijanskoga iredentizma nego i protiv austrijskih vlasti, u koje su se još početkom stoljeća polagale velike nade. Usto su se nizali zahtjevi za reformu države, a stalna je pojava bila i idealizacija Srbije: „Kardinalni je zahtjev uklanjanje dualizma; pozitivan zahtjev: priznanje aneksije balkanskih država gotovo cijele europske Turske. Narodna samouprava ili 'homerule', i sve dok je takva unutarnja državnopravna promjena nemoguća, upravna koncentracija Jugoslavena u jedan realan politički subjekt umjesto mnogih povijesno-političkih individualiteta, te samostalna Hrvatska koja bi bila povezana s Ugarskom toliko koliko je i Ugarska s Austrijom; carinski, a poslije i politički savez s balkanskom federacijom." ${ }^{76}$ Čak i umjereni „naprednjaci”, kako su liberali sami sebe zvali, izražavali su veselje zbog događaja u balkanskim ratovima i vidjeli priliku za povezivanje Habsburške Monarhije s novim balkanskim savezom, dakako nakon reforme same Monarhije. Usto su se nastavljali napadi na ideju trijalizma: „Zašto nam trijalizam nije simpatičan. On bi nam možda neposredno koristio ako bismo mislili egoistički samo na jugoslavenske koristi. No $\mathrm{u}$ trenutku kad Austrija postane trijalistička, to postaje akutno pitanje za veliku Njemačku, to jest udruživanje pretežno njemačke trećine s Njemačkom, što ne bio samo povod za nove europske komplikacije nego i udarac protiv Čeha. Bez obzira na to velika bi Njemačka mogla postati nama samima opasnija negoli je sad [...] te bi tako Jugoslaveni bez obzira na Ugare bili izloženi dvjema državnim imperijalnim težnjama, njemačkom pangermanizmu i ruskom panslavizmu. [...] Mi [...] se zauzimamo za kulturne veze između svih Slavena, zahtijevamo samoupravu i neovisnost Balkana, sve to u takvu državnopravnom obliku u kojem bi velika Austrija stupila u vezu s balkanskim savezom te bi taj savez bio politički izraz postojeće gospodarske i zemljopisne zajednice Podunavlja i Balkana. [...] takva [...] organizacija srednje i jugoistočne Europe [...] održavala bi ravnotežu Rusiji, Engleskoj i Italiji." ${ }^{\prime 68}$ Neki su i radikalnije

Kamorkoli gledamo, kamorkoli se oziramo, vidimo na vseh poljih javnega življenja, da se naše ljudi, naš element, naš narod, preganja in zatira - da je ves državni sistem urejen $v$ to, da so Nemci in Italijani favorizirani, a Slovenci zapostavljeni! ... Ravno zato pa treba, da povemo gospodom na Dunaju odkrito in brez ovinkov, da danes sicer še ni govora o Jugoslovanskem iredentizmu, da pa ne bi bilo nikako čudo, ko bi se jel porajati. ... V Srbiji vlada popolna državljanska enakost, tam je urejena demokratična uprava in popolna politična svoboda („Jugoslovani in Avstrija”, Edinost, 1. 12. 1912., 1).

67 Kardinalna zahteva je: odprava dualizma; pozitivna zahteva: priznanje aneksije skoro cele evropske Turčije od strani balkanskih držav. Narodna samouprava ali homerule, in dokler je taka državnopravna notranja izprememba nemogoča, upravna koncentracija Jugoslovanov $v$ eno realno politično individualiteto namesto mnogih historično-političnih individualitet, in samostalna Hrvatska, ki bi bila z Ogrsko zvezana le v toliko v realni uniji, kakor Ogrska z Avstrijo; carinska in kasneje tudi politična zveza z balkansko federacijo („Jugoslovansko vprašanje”, Soča, 1. 2. 1913., $1-2)$.

$68 \quad$ Zakaj nam trializem ni simpatičen. On bi nam morda neposredno koristil, če bi mi mislili le egoistično na samo jugoslovanske koristi. V trenutku pa, ko je Avstrija trialistična, postane akutno vprašanje velike Nemčije, t.j. združitve pretežno nemške tretjine z Nemčijo, kar bi ne bilo le nov 
pozivali na upotrebu ljudske i vojne moći južnoslavenskih naroda u rješavanju odnosa s Bečom: „Ono što su Jugoslaveni naučili iz velike 1912. godine dragocjenije je od svih knjižnica o povijesti naše slavne prošlosti [...] Godina 1912. i previše nam je otvorila oči da bismo se mogli uhvatiti u slične zamke bečkih Metternicha [...] između Hrvata i Srba na jednoj i današnjega Beča na drugoj strani postoji idiosinkrazija [...] koju ne mogu ukloniti nikakve idilične izložbe, kongresi i govori, nego samo naša pesnica i naša snaga koju su nam opet dale žrtve naših suplemenika na Balkanu [...] na posao!!’69

Ipak, nisu se sva očekivanja slovenskih liberala obistinila. Uskoro je naime na vidjelo izašao konkurentski odnos pojedinih članica balkanske koalicije. Najprije su Crnogorci ostali bez Skadra, čiju su obranu nakon dugotrajne opsade napokon slomili u travnju 1913. godine. Od toga su ratnoga plijena morali odustati jer se Habsburška Monarhija već bila počela pripremati za vojnu intervenciju. Srbija je još prije anticipirala moguće komplikacije i maknula svoje snage s teritorija koji su velesile namijenile Albaniji te se usmjerila rješavanju spornih pitanja s Bugarskom. Imala je potporu Rusije da joj se pripoje Bitola i Ohrid, ${ }^{70}$ a sam je Pašić nove ambicije, suprotne predratnom dogovoru s Bugarskom, opravdavao kao „force maior” budući da Srbija nije dobila sve teritorije, koje su velike sile priključile Albaniji, što bi trebalo značiti da je srpsko-bugarski sporazum ništavan. ${ }^{71} \mathrm{Za}$ to vrijeme srpska se vojska već pripremala za okršaj; u Makedoniji su zatvorene sve bugarske institucije, a brojni su bugarski činovnici i svećenici zatvarani. Takvu je situaciju iskoristila i Rumunjska, koja je vidjela mogućnost za promjenu bugarsko-rumunjske granice. Čini se da ni Sofija na drugoj strani nije ulagala dovoljno napora u pokušaj sprječavanja sukoba, nego je naivno vjerovala da Rusija neće dopustiti kršenje predratnih dogovora. I Grčka je stala na stranu Srbije, čime je pokušala osigurati savez koji će joj pomoći u osvajanju Soluna. Na sve to treba dodati i činjenicu da

\footnotetext{
povod evropskim komplikacijam, marveč tudi udarec proti Čehom. Ne glede na to bi tudi velika Nemčija utegnila postati nam nevarnejša nego je zdaj (...) ter bi tako Jugoslovani ne glede na Ogre bili izpostavljeni dvema državnima imperialističnima težnjama, nemškemu pangermanizmu in ruskemu panslavizmiu. ... Mi (...) se zavzemamo za kulturne stike med vsemi Slovani, zahtevamo samoupravo in neodvisnost Balkana, vse to pa v taki državnopravni obliki, da bi velika Avstrija stopila $v$ zvezo z balkansko zajednico, ter bi bila ta zveza politični izraz obstoječe gospodarske in zemljepisne skupnosti Podonavja in Balkana. ... taka (...) srednje in jugovzhodna evropska organizacija (...) bi držala v orientu ravnotežje Rusiji, Angliji in Italiji (Isto).

69 Kar so se Jugoslovani naučili iz velikega leta 1912, je dragoceneje, nego vse biblijoteke o zgodovini naše slavne minolosti ... Leto 1912. nam je preveč odprlo oči, da bi padali v slične pasti dunajskih Metternichov ... med Hrvati in Srbi na eni, in današnjim Dunajem na drugi strani obstoji idiosinkrazija, ... ki je ne morejo odpraviti nikake idilične razstave, kongresi in govori, ampak le naša pest in naša moč, ki so nam jo zopet porodile žrtve naših soplemenjakov na Balkanu ... na delo!! („Ivo Vojnović”, Edinost, 19. 1. 1913., 2).

70 „Diference med Srbijo”, Edinost, 22. 4. 1913., 1.

71 „Kritičen položaj”, Edinost, 29. 5. 1913., 1; „Kritičen položaj”, Edinost, 30. 5. 1913., 2.
} 
Bugarska ni s Turskom još nije potpuno završila rat, što ju je stavljalo u bezizlazan položaj. Toga je bila svjesna i Rusija, koja je već prijedlogom kompromisnoga sporazuma u bugarsko-rumunjskom sporu Sofiji dala na znanje da joj neće nuditi zaštitu po svaku cijenu. Kad su već bili počeli otvoreni konflikti između Grka i Bugara, Edinost je još uvijek pisala samo o „diferencijama među saveznicima”. Da su te razlike prerasle u oružani sukob objavljeno je tek krajem svibnja 1913. godine. ${ }^{72} \mathrm{O}$ zaoštravanju srpsko-bugarskoga odnosa isti je list pisao najprije objektivno, no ubrzo je bilo moguće primijetiti priklanjanje srpskim stavovima. Edinost je osudila bugarska tumačenja prema kojima su Makedonci zapravo dio bugarskoga naroda, ${ }^{73}$ no još je više nastupala protiv austrijske politike koja je poticala „bratoubilački rat”. ${ }^{74}$ Zbog premoći nove protubugarske koalicije i činjenice da Bugarska nije na vrijeme angažirala cijeli svoj vojni potencijal ${ }^{75}$ te kad je već bilo jasno da nema izgleda izaći iz sukoba kao pobjednik, Edinost je i izravno optužila Sofiju za eskalaciju rata te nekritički prenosila pisanje srpskih časopisa. ${ }^{76}$ Edinost je dakle u tršćanskom kontekstu prenosila slične informacije kao primjerice Riječke novine u Rijeci ${ }^{77}$ te interpretirala događanja poput većine hrvatskih časopisa pod kontrolom Hrvatsko-srpske koalicije. ${ }^{78}$

Bugarski poraz nije nikoga iznenadio. Edinost je za trpljenje bugarskoga naroda okrivila upravo bugarski politički vrh, a Srbe je hvalila za milost koju su pokazali time što nisu potpuno uništili bugarsku državu: „Jedino moguće pravilno nacionalno stajalište južnoslavenstva jest da je pravo na strani Srbije [...] Valjda ne treba ponavljati da je Srbija učinila sve moguće [...] da spor riješi mirno. No i pored sve jedinstvenosti i širokogrudnosti jugoslavenskoga patriotizma srpskih državnika Srbija nije mogla odvratiti bezglave bugarske državnike od opasna puta na koji su odveli Bugarsku golemom pretencioznošću i za južnoslavenstvo nepravednom sebičnošću. [...] Rat je izazvala Bugarska, vođena izdajničkom mišlju da razbije Srbiju i njezinu državno-nacionalnu neovisnost učini iluzornom te ju tako za sva vremena onesposobi za rješavanje nacionalnoga pitanja." ${ }^{79}$ Drukčiji je stav Edinost zauzela samo glede

\footnotetext{
„Bolgarske izgube pri spopadih z Grki”, Edinost, 23. 5. 1913., 1.

„Bolgarska in srbska akademija”, Edinost, 6. 6. 1913., 2.

„Balkanska vojna”, Edinost, 22. 5. 1913., 1; „Grobokopi Jugoslovanstva”, Edinost, 8. 7. 1913.

DESPOT, The Balkan Wars, 173.

„Splošno prodiranje bolgarske”, Edinost, 1. 7. 1913., 1-2; „Prve srbske čete”, Edinost, 5.7. 1913., 1-2.

77 MATIJEVIĆ, „Balkanski ratovi”.

78 DESPOT, „Tisak Hrvatske i Dalmacije”.

79 Jedino mogoče pravilno nacionalno stališče južnega Slovanstva obstoji v tem, da je pravo na strani Srbije ... Menda ni treba tudi sedaj še ponavljati, da je Srbija storila vse mogoče ... da bi se spor rešil mirnim potom. A poleg vse unitarnosti in širokosrčnosti Jugoslovanskega patrijotizma
} 
Rumunjske, koja je „licemjerno iskoristila bugarsku nemoć”. ${ }^{80}$ Čini se ipak da je neslavenstvo Rumunja zapravo bilo jedini razlog za različit prikaz Rumunja i Srba u tom časopisu.

\section{Posljedice}

Drugi krug balkanskih ratova bitno je promijenio mogućnost realizacije panslavenske ideje ili bar šire južnoslavenske ideje u obliku neke nove federacije na Balkanu koju su priželjkivali u Edinosti. Ta su događanja posljedično reducirala pojam ,jugoslavenski narod”, iz kojega su isključeni Bugari. Slovenski panslavisti i zagovornici najširega južnoslavenskoga koncepta odustali su od svojih ideala, no pritom nisu bili svjesni da se udaljavanjem geopolitičkoga centra priželjkivane južnoslavenske države povećava opasnost od periferizacije zapadnih primorskih krajeva. Upravo u toj činjenici, koja je trebala rezultirati smanjenjem vrijednosti toga područja u očima južnoslavenskih političkih predstavnika, Talijani su - kao primjerice iredentistički spisatelj Ruggero Fauro Timeus - vidjeli svoju priliku: „Do jučer je cilj austrijskih Slavena bio trijalizam koji je implicirao stvaranje slavenskoga kraljevstva u Austriji sastavljenog od Hrvatske, Dalmacije, Bosne, Kranjske i Julijske krajine. Glavni bi grad bio obavezno Trst. To je i izvor njihova angažmana, žele ga slavenizirati. Pored toga jezgra slavenske države trebala bi biti u njegovu zaleđu: bez njega i bez Istre ostala bi odrezana od mora. Ako pak tim pokrajinama dodamo Srbiju, Staru Srbiju, Sandžak, gravitacijski se centar i zemljopisno i gospodarski pomiče prema jugu. Glavni grad nove Slavije mora postati Beograd, njezine glavne luke Split i Solun. Slavenima Trst više nije potreban." ${ }^{81}$ Srpski je uspon dakle uzrokovao upravo ono zbog čega je Edinost odbacivala ideje poput hrvatskoga „novoga kursa” ili užega trijalizma. Interesantna je činjenica da to ovoga puta nije bio slučaj, upravo suprotno. Naime, Edinost je izdavala i časopis Jugoslavija, koji je promovirao pretežno srpsku ideju jugoslavenstva, a čiji je

srbskih državnikov ni mogla Srbija zadržati brezglavih bolgarskih državnikov od nevarne poti, na katero sta dovedli Bolgarsko grandomanska pretencijoznost in za južno Slovanstvo krivična sebičnost. ... Vojno je izzvala Bolgarska, gnana od izdajalske misli, da zlomi Srbijo, da državno-nacijonalno neodvisnost te poslednje napravi iluzorno in da jo na ta način za vse čase onesposobi za reševanje nacijonalnega vprašanja („,Druga balkanska vojna”, Edinost, 22. 7. 1913., 1).

80 „Balkanska vojna”, Edinost, 13. 7. 1913., 11.

81 Do včeraj je bil cilj avstrijskih Slovanov trializem, kar pomeni ustanovitev slovanskega kraljestva v Avstriji, ki naj bi ga sestavljale Hrvatska, Dalmacija, Bosna, Kranjska in Julijska Benečija. Glavno mesto bi bilo pri tem obvezno Trst. Od tod tudi njihova zagnanost, da ga slavizirajo. Poleg tega naj bi bilo jedro slovanske države v njegovem zaledju: brez njega in brez Istre bi ostala odrezana od morja. Če pa tem pokrajinam pridružimo Srbijo, staro Srbijo, Sandžak, se gravitacijski center tako zemljepisno kot gospodarsko premakne proti jugu. Glavno mesto nove Slavije mora postati Beograd, njeni poglavitni pristanišč Split in Solun. Slovanom Trst ni več potreben (PIRJEVEC, Trst je naš!, 56). 
tisak u svibnju 1914. preseljen u Prag, gdje je postao glasilo Jugoslavenske nacionalne omladine. Ipak, i među slovenskim liberalima nije postojala potpuna jednoglasnost u vezi s podupiranjem južnoslavenske državne tvorbe sa Srbijom i bez Bugarske. Postoje i primjeri, doduše rijetki, koji pokazuju da su naprimjer pojedinci u krugu goričke Soče sa zakašnjenjem ipak uvidjeli svoj položaj u južnoslavenskom kontekstu: „Događaji u Italiji pokazuju najnovije tendencije $\mathrm{u}$ talijanskoj politici. Ta je politika usmjerena u prvom redu protiv nas, Slovenaca i Hrvata. [...] Italija se danas priprema za rat i zauzimanje cijele obale od izvora Soče do Boke kotorske. [...] I što je još zanimljivije, pritom računa na potporu Srbije." 82 Možemo zaključiti da su u određenom razdoblju brojni slovenski liberali iz Trsta i Gorice bili vjerojatno i najiskreniji zagovornici južnoslavenske državne ideje. Istina je da ih je pritom vodio motiv slovenskih interesa, no samo su rijetki izražavali distinkciju između jugoslavenstva i slovenstva. Posljedično je i razočaranje južnoslavenskom nejedinstvenošću bilo izraženije. Najprije srpsko-hrvatski i potom srpsko-bugarski konflikti uzrokovali su zbunjenost slovenskih liberala, što je uz nedovoljno razumijevanje geopolitičke realnosti utjecalo i na njihovu političku marginalizaciju u širem južnoslavenskom kontekstu te uz vanjske okolnosti doprinijelo i neostvarenju cilja priključenja Primorske i Trsta slovenskoj matici.

\footnotetext{
82 Manifestacije v Italiji kažejo najnovejše tendence italijanske politike. Ta politika je naperjena najprvo proti nam, Slovencem in Hrvatom. ... Italija se dandanašnji pripravlja na vojno, da zajame celo obalo od izvira Soče do Boke Kotorske. ... Iti kar je še zanimivejše, pri tem se računa na podporo Srbije („Italija, Avstrija in Jugoslovani”, Soča, 16. 5. 1914., 1).
} 


\section{Objavljeni izvori i tisak}

Edinost (Trst), 1887, 1908-1909, 1911-1913.

Soča (Gorica), 1909-1914.

\section{Literatura}

BAKIĆ, Jovo. Ideologije jugoslovenstva izmedu srpskog i hrvatskog nacionalizma 1918-1941. Zrenjanin: Gradska narodna biblioteka „Žarko Zrenjanin”, 2004.

BESHIRI, Ismije. „Neovisnost Albanije 1912. na temelju njemačke diplomatske dokumentacije". Časopis za suvremenu povijest 51 (2019), br. 1: 253266.

BISTER, Feliks J. „Hrvaško-slovensko sodelovanje v dunajskem parlamentu na predvečer prve svetovne vojne”. Pilar - Croatian Journal of Social Sciences and Humanities 4 (2009), br. 1-2: 103-110.

BRUCKMÜLLER, Ernst. „Nove raziskave zgodovine avstrijskega meščanstva”. Zgodovinski časopis 4 (1991), br. 3: 369-389.

CVIRN, Janez. „Med nacionalizmom in nacionalno koeksistenco”. Zgodovinski časopis 63 (2009), br. 1-2: 228-238.

CVIRN, Janez. Razvoj ustavnosti in parlamentarizma v Habsburški monarhiji: Dunajski državni zbor in Slovenci (1849-1918). Ljubljana: Filozofska fakulteta, 2006.

DESPOT, Igor. „Balkanski ratovi (1912. - 1913.) i hrvatska javnost”. Magistarski rad, Filozofski fakultet Sveučilišta u Zagrebu, 2008.

DESPOT, Igor. The Balkan Wars in the Eyes of the Warring Parties. Perceptions and Interpretations. Bloomington: iUniverse, Inc., 2012.

DESPOT, Igor. „Tisak Hrvatske i Dalmacije o balkanskim ratovima (19121913)”. Historijski zbornik 62 (2009), br. 1: 109-135.

GABRŠČEK, Andrej. Goriški Slovenci-narodne, kulturne, politične in gospodarske črtice, knj. 2: Od leta 1901 do 1924. Ljubljana, 1934.

GRDINA, Igor. Slovenci med tradicijo in perspektivo: politični mozaik 18601918. Ljubljana: Študentska založba, 2003.

HALL, Richard C. The Balkan Wars 1912-1913. Prelude to the First World War. London; New York: Routledge, 2000.

KACIN-WOHINZ, Milica; TROHA, Nevenka. Slovensko-italijanski odnosi 1880-1956. Poročilo slovensko-italijanske zgodovinsko-kulturne komisije. Ljubljana: Nova revija, 2001. 
KLABJAN, Borut. Češkoslovaška na Jadranu. Koper: Založba Annales, 2007.

KOCUTAR, Stanislav. „Habsburška monarhija in jugoslovansko vprašanje v luči slovenske historiografije". Pilar - Croatian Journal of Social Sciences and Humanities 4 (2009), br. 1-2: 11-35.

LAMPE, John R. Yugoslavia as history. Twice there was a country. Cambridge: Cambridge University Press, 2002.

MARUŠIČ, Branko. „Od Maribora do Trsta 1850-1914”. Zgodovinski časopis 52 (1998), br. 3: 453-455.

MATIJEVIĆ, Zlatko. „Balkanski ratovi na stranicama 'Riječkih novina' (1912-1913)". U: Tkivo kulture. Zbornik Franje Emanuela Hoška u prigodi 65. obljetnice života, ur. Nela Veronika Gašpar. Zagreb; Rijeka: Kršćanska sadašnjost; Teologija u Rijeci, 2006, 189-215.

MATKOVIĆ, Stjepan. „Ivan Tavčar i njegov odnos prema Hrvatskoj”. U: Tavčarjev zbornik, ur. Igor Grdina. Ljubljana: Založba ZRC SAZU, 2015, 151159.

MATKOVIĆ, Stjepan. „Political Narratives in Croatia in the Face of War in the Balkans". U: The Balkan Wars from Contemporary Perception to Historic Memory, ur. Katrin Boeckh i Sabine Rutar. London: Palgrave Macmillan, 2016, 179-196.

MILLO, Anna. L'elite del potere a Trieste: una biografia collettiva 1891-1938. Milano: Franco Angeli Storia, 1989.

PAHOR, Milan. Slavjanska sloga. Slovenci in Hrvati v Trstu. Od avstroogrske monarhije do italijanske republike. Trst: ZTT EST, 2004.

PEČENKO, Valentin, ur. Cesarski Trst in Slovenci. 2. del: Preporod (audiovizualni materijal, dokumentarna emisija). Ljubljana: TV Slovenija, 2013. Pristup ostvaren 5. 5. 2014. ava.rtvslo.si/predvajaj/cesarski-trst-in-slovenci-preporod-dokumentarna/ava2.174296892/.

PIRJEVEC, Jože. Trst je naš! Boj Slovencev za morje (1948-1954). Ljubljana: Nova revija, 2007.

PLETERSKI, Janko. „Trializem pri Slovencih in jugoslovansko zedinjenje”. Zgodovinski časopis 22 (1968), br. 1: 169-184.

RAHTEN, Andrej. Slovenska ljudska stranka v Dunajskem parlamentu. Slovenska parlamentarna politika v Habsburški monarhiji 1897-1914. Celje: Cenesa; Založba Panevropa, 2001.

RAHTEN, Andrej. Zavezništva in delitve: razvoj slovensko-hrvaških političnih odnosov v habsburški monarhiji 1848-1918. Ljubljana: Nova revija, 2005. 
SAJOVIC, Bogdan. Od male Srbije do velike Jugoslavije. Ljubljana: Založba Karantanija, 2006.

Spezialortsrepertorium für das österreichisch-illyrische Küstenland: bearbeitet auf Grund der Ergebnisse der Volkszählung vom 31. Dezember 1910 / herausgegeben von der K. k. statistischen Zentralkommision. Spezialortsrepertorium der österreichisch Länder 7. Wien: K. k. Hof- und Staatsdruckerei, 1918.

STANKOVIĆ, Đorđe. Nikola Pašić, saveznici i stvaranje Jugoslavije. Beograd: Nolit, 1984.

VERGINELLA, Marta. Družina v Dolini pri Trstu v 19. stoletju. Ljubljana: Zveza zgodovinskih društev Slovenije, 1990.

VERGINELLA, Marta. „Prihod vlaka v Trst”. Zgodovina za vse - vse za zgodovino 42 (1997), br. 2: 59-65.

VERGINELLA, Marta. „Zgodovinjenje slovensko-italijanske meje in obmejnega prostora”. Acta Histriae 18 (2010), br. 1-2: 207-216.

VIVANTE, Angelo. Irredentismo adriatico. Firenze: Parenti, 1954.

WINKLER, Eduard. Wahlrechtsreformen und Wahlen in Triest 1905-1909: eine Analyse der politischen Partizipation in einer multinationalen Stadtregion der Habsburgermonarchie. München: R. Oldenburg, 2000.

ZAJC, Marko. Slovenci in protislovja južnoslovanskih integracijskih ideologij do 1914. Ljubljana: Inštitut za novejšo zgodovino, 2010. 


\section{SUMMARY}

\section{The Geopolitical Shift of Slovenian Liberal Circles in Primorska on the Eve of World War I}

The author analyses the writings of Slovene journals from the Primorska (Slovene Littoral) region in the period of the Balkan Wars, in the years 1912 and 1913. The article presents the shift of liberal Slovenes' attitudes towards the Yugoslav idea and places it in the broader context of the conflict between various geopolitical ideas. The specific position of the Primorska region and Istria as well as the consequential geopolitical importance of Trieste were reflected in the inclination of those liberal Slovenians to the broader concept of the Yugoslav political idea, which included all South Slavic nations and was supposed to be the leverage for Slovenian political emancipation. Initially, the Slovene liberals, who were gathered in the political group named Edinost (Unity) in Trieste and around the journal Soča in Gorizia, favoured the idea of a third political unit within the Habsburg Monarchy, with the ambition of including Trieste and Gorizia into that entity. However, due to fears of being left outside of that third unit, these Slovenes abandoned so called 'trialist' idea. The defeats of the Ottoman Empire in the first round of the Balkan Wars resulted in omitting the Habsburg context in Slovene journals from the Primorska region, while the second round caused the exclusion of Bulgaria from the South Slavic state concepts, and pushed those Slovenes towards the narrower version of the Yugoslav idea, where Serbia was to have a central role.

Key words: Balkan wars; Primorska (Slovene Littoral); Yugoslav idea; Trieste; geopolitics 